\title{
建物規模・用途別の熱源システム採用状況を考慮した 地域冷暖房施設導入可能性評価に関する研究 \\ ESTIMATION OF APPROPRIATENESS OF AREAS FOR DISTRICT HEATING AND COOLING SYSTEM CONSIDERING THE DISTRIBUTION OF BUILDING HEAT SOURCE SYSTEM
}

\author{
山口容平*, 下田吉之**
}

Yohei YAMAGUCHI and Yoshiyuki SHIMODA

\begin{abstract}
There are a number of studies that evaluate the appropriateness of areas for district heating and cooling systems. While heat demand density is used as the indicator for the evaluation, this method assumes that all the buildings in the evaluated district are connected to district heating and cooling system. This assumption brings overestimation when the method is applied to existing districts since there are buildings that equip package air-conditioning systems and cannot connect to district heating and cooling system due to the absence of heat delivery pipelines. This paper evaluates the extent to which the conventional evaluation method overestimates the appropriateness of areas via a case study for districts of Osaka city if the stock of heat source systems is taken into account. The result of the case study showed that although there exists 78 districts (500m square area) with a annual heat demand density larger than 4.2 TJ/ha (1 Tcal/ha) in Osaka city, the number of districts satisfying the condition of heat demand density decreases to 33, if buildings equipping distributed heat source system are excluded. The total annual heat demand in the selected areas decreases from $21 \mathrm{TJ} / \mathrm{ha}$ to $6 \mathrm{TJ} / \mathrm{ha}$.
\end{abstract}

Keywords : District Heating and Cooling System, Evaluation, Heat demand density, Heat-source system, District-level simulation 地域冷暖房，導入可能性評価，熱負荷密度，熱源システム，地域シミュレーションモデル

\section{1. はじめに}

地域冷暖房施設は省エネルギー、環境負荷削減に有効であるとい われ、今後も多数の地域で導入が検討されると考えられる。佐土原 ら ${ }^{1)}$ は日本全国を対象として地域冷暖房施設の導入に適した地域を 抽出しており、抽出された地域は全国で 1302 地区存在し、抽出され た地区の熱需要は約 $260 \mathrm{PJ} /$ 年に達する。地域冷暖房施設の導入によ り得られる一次エネルギー消費量の削減量は約 90PJ/年（日本のエ ネルギー消費の $0.6 \%$ に相当）と推計されている。この研究成果は地 域冷暖房施設導入の有用性を示すとともに、地域冷暖房施設の導入 を計画するうえで有用な基礎資料を提供している。

佐土原らは地域冷暖房施設に適した地域の抽出において、地域の 年間冷温熱需要の合計值を地域面積で除した数值として定義される 熱負荷密度を指標として用い、熱負荷密度が $1 \mathrm{~T}$ cal/ha・年以上であ ることを抽出の条件とした。佐土原らのほかにも、東京 ${ }^{2)}$ 、埼玉 ${ }^{3)}$ 、 九州 ${ }^{4)}$ 、大阪 ${ }^{5)}$ を対象として地域冷暖房施設の導入可能地区の選定
が行われているが、いずれの研究も地域の熱負荷密度を判定の指標 として用いている。また、前述の佐土原らの研究は、地域冷暖房施 設の導入可能性がある地域の大部分が既成市街地であると述べてい る（抽出された地域冷暖房導入可能地区の $72.5 \%$ )。

既成市街地の場合、地域冷暖房施設の導入は地域に立地寸る建物 の建替えや設備更新にあわせて段階的に行われると考えられるが、 必ずしもすべての建物が地域冷暖房配管に接続できるわけではない。 特に、近年ビルマルチやガスヒートポンプなどの個別分散型空調シ ステムを採用している建物が増加しているが、個別分散型空調シス テムを導入している建物は冷暖房用の冷温水配管や空調機を持たな いことから、建替えが行われない場合、想定される需要家は地域冷 暖房施設からの熱供給を受けることができない。したがって、既成 市街地を対象として地域冷暖房施設の導入可能性を判定する場合、 短中期的な視点においてはセントラル方式を採用している建物に需 要家を限定する必要があり、全建物を対象として推計された熱負荷
* 大阪大学大学院工学研究科環境 - エネルギー工学専攻

助教・工博

** 大阪大学大学院工学研究科環境・エネルギー工学専攻 教授・工博
Assistant Prof., Division of Sustainable Energy and Environmental Engineering, Graduate School of Engineering, Osaka University, Dr. Eng.

Prof., Division of Sustainable Energy and Environmental Engineering, Graduate School of

Engineering, Osaka University, Dr. Eng. 
密度に基づく評価の結果は過大となる可能性があると考えられる。 以上の背景から、本研究では著者らが開発した業務用建築設備デ ータベース、地区類型エネルギー需要推計モデル（次節に説明する） を用いることで空調熱源システムの採用状況を考慮して地域におけ る熱需要を推計することを検討する。具体的には、大阪市を対象と して地域冷暖房施設導入可能性評価を行うことを想定し、地区に立 地するすべての建物を対象として推計される熱負荷密度と、個別分 散型空調システムを採用している建物を除いて推計される熱負荷密 度を推計し、両者の差異を明らかにすることを目的とする。特に、 地区の特徵と差異の関係を明らかにする。

\section{2. 地域冷暖房施設導入可能性評価の方法}

著者らは既報 ${ }^{6)}$ において、業務建築ストックにおける熱源システ ムの採用状況を業務建築の用途別、規模別に整理している。ここで は 1984 年から 2006 年に空気調和・衛生工学会に発表された竣工設 備データ ${ }^{7)}$ をンプルとして、セントラル方式、個別分散型空調方 式の採用率を用途別・規模別に算出した。竣工設備データでは冷熱 源機器、温熱源機器の種類と機器別の容量が集計されており、この うち最も容量の大きい冷熱源機器、温熱源機器を抽出し、ビルマル チ、パッケージェアコン、ガスヒートポンプのいずれかであれば個 別分散型空調方式、そのほかの熱源機器であればセントラル方式を 採用している建物とした。ただし、用途別の規模区分は表 1 のもの を用いた。表 1 の規模区分は、大阪市固定資産税課税台帳に記載さ れている業務建築の延床面積データから作成したもので、規模区分 を閾值として延床面積 $2000 \mathrm{~m}^{2}$ 以上の業務建築を区分し、区分内の総 延床面積を算出すると、大阪市全体の総延床面積は同程度になるよ うに決定されている ${ }^{6)}$ 。

表 1 用途別床面積区分

\begin{tabular}{|c|c|c|c|c|c|}
\hline 用途 & 規模区分 & 1 & 2 & 3 & 4 \\
\hline 事務所 & & $\begin{array}{r}2,000 \mathrm{~m}^{2} \\
\text { 未満 }\end{array}$ & $\begin{array}{r}2,000 \mathrm{~m}^{2} \\
-6,000 \mathrm{~m}^{2}\end{array}$ & $\begin{array}{r}6,000 \mathrm{~m}^{2} \\
-30,000 \mathrm{~m}^{2}\end{array}$ & $\begin{array}{c}30,000 \mathrm{~m}^{2} \\
\text { 以上 }\end{array}$ \\
\hline 商業 & & $\begin{array}{r}2,000 \mathrm{~m}^{2} \\
\text { 未満 }\end{array}$ & $\begin{array}{r}2,000 \mathrm{~m}^{2} \\
-8,000 \mathrm{~m}^{2}\end{array}$ & $\begin{array}{r}8,000 \mathrm{~m}^{2} \\
-50,000 \mathrm{~m}^{2}\end{array}$ & $\begin{array}{c}50,000 \mathrm{~m}^{2} \\
\text { 以上 }\end{array}$ \\
\hline 宿泊 & & $\begin{array}{r}2,000 \mathrm{~m}^{2} \\
\text { 未満 }\end{array}$ & $\begin{array}{r}2,000 \mathrm{~m}^{2} \\
-15,000 \mathrm{~m}^{2}\end{array}$ & $\begin{array}{r}15,000 \mathrm{~m}^{2} \\
-100,000 \mathrm{~m}^{2}\end{array}$ & $\begin{array}{r}100,000 \mathrm{~m}^{2} \\
\text { 以上 }\end{array}$ \\
\hline 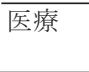 & & $\begin{array}{r}2,000 \mathrm{~m}^{2} \\
\text { 未満 }\end{array}$ & $\begin{array}{r}2,000 \mathrm{~m}^{2} \\
-6,000 \mathrm{~m}^{2}\end{array}$ & $\begin{array}{r}6,000 \mathrm{~m}^{2} \\
-30,000 \mathrm{~m}^{2}\end{array}$ & $\begin{array}{c}30,000 \mathrm{~m}^{2} \\
\text { 以上 }\end{array}$ \\
\hline
\end{tabular}

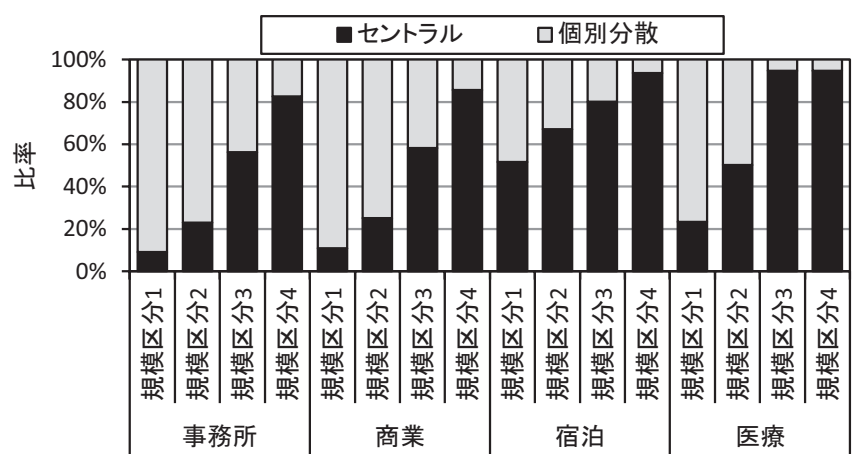

図 1 用途別・規模別熱源システム採用率

結果を図 1 に示す。図 1 より熱源システムの採用状況は建物規模、 用途によって異なることがわかる。このようなデータを用いること
によって地域冷暖房施設が導入された場合に需要家となる可能性が 高い建物、つまり、セントラル方式を採用している建物に限定して 熱需要を推計することが可能となる。

しかし、図 1 に示した空調熱源システムの採用状況を考慮するた めには、評価対象地区における個々の建物の規模、用途を把握する 必要性が生じる。これに対して、著者らは地区を単位としてエネル ギー需要、エネルギー消費量を推計する手法（地区類型エネルギー 消費推計モデル）を開発してきた ${ }^{8)}$ 。本手法を熱需要推計部分のみ 取り出すと図 2 に示寸手順となる。

まず、500 メートルメッシュデータを用いて、メッシュ別に建築 の集積状況を表すパラメータを整備し、メッシュを類型化する。次 に、ここで得られた類型を地区類型とし、各地区類型を代表するメ ッシュを選択し、これを代表地区とする。代表地区を対象として、 地区内に立地するすべての業務建築について冷温熱需要、給湯需要 を推計する。ここではセントラル方式、個別分散型方式を想定して シミュレーションを行い、その結果を図 1 に示したシェアで重みづ け平均し、個々の建物の熱需要とする。得られた熱需要の積算值を 総延床面積で割って原単位化し、地区類型別の原単位と寸る。この ような手順を踏むことによって得られた原単位は空調熱源システム の採用状況をはじめ、代表地区に集積する建物の大きさや形状、用 途の影響を含むものとなる。最後に、ここで得られた原単位を地区 類型全体に適用し、検討の対象とするすべての地区の熱需要を推計 する。

手順(1) 建築集積状況に関するメッシュデータの整備と対象 地域の地区類型化

\section{$\downarrow$}

手順(2) 地区類型別の代表メッシュの選出と代表メッシュの 建築ストック集積状況の調查

\section{$\downarrow$}

手順(3) 代表メッシュにおける設備ストック集積状況の予測 $\downarrow$

手順(4) 建築ストックの集積状況、設備ストックの集積状況を 考虑した地区類型代表メッシュ熱需要(冷温熱、給湯)シミュ レーションと結果に基づく地区類型別熱需要原単位の決定 $\downarrow$

手順(5) 地区類型別原単位を用いた対象地域内すべての メッシュにおける熱需要の推計

図 2 地区類型に基づくエネルギー需要モデルの開発手順

本研究ではケーススタディの対象として大阪市を採用した。ケー ススタディでは、大阪市域を 500 メートル四方のメッシュに分割し、 各メッシュの熱負荷密度を推計し、熱負荷密度 $1 \mathrm{Tcal} / \mathrm{ha}$ ・年を閾值 として地域冷暖房施設の導入可能性評価を行う。ただし、熱負荷密 度の推計において、空調熱源システムの採用状況を考慮し、個別分 散型空調システムを採用している建物の熱需要を考慮外とすること によって評価結果にどの程度の差異が生じるか明らかにする。具体 的には、図中手順(4)の代表地区における原単位の推計過程において、 個別分散型空調システムを採用している建物の熱需要をゼロとする ことで、セントラル方式を採用している建物のみの熱需要を推計す ることが可能となる。

最後に、大阪市の全メッシュを対象として熱負荷密度を推計し、 地域冷暖房施設の導入可能性評価を行う。まず、各地区類型の熱需 
要原単位を地区類型別の床面積とかけあわせ、メッシュ別の熱需要 を推計する。ここでは全建物の熱需要、また、地域冷暖房施設の需 要家となる可能性があるセントラル方式を採用している建物の熱需 要をそれぞれ推計し、その結果から熱負荷密度を算出する。得られ た熱負荷密度を判定条件である $1 \mathrm{~T} \mathrm{Tca} / \mathrm{ha}$ ・年 $(105 \mathrm{TJ} /$ メシシュ・年) と比較し、地域冷暖房システム導入可能性地区を抽出する。

以下では各手順について方法の詳細を説明する。

\section{(1) 大阪市の地区類型}

大阪市計画調整局作成の $500 \mathrm{~m} \times 500 \mathrm{~m}$ メッシュを用いて、表 2 に 示寸データを整備した。このメッシュデータにより大阪市域は 971 のメッシュに分類される。まず、メッシュ内の建物用途別床面積の データ整備方法を説明する。

表 2 地区類型化に用いたパラメータ

\begin{tabular}{ll}
\hline 変数 & 説明 \\
\hline メッシュ内の建 & 事務所、商業（飲食・物販・遊興など）、宿泊、医 \\
物用途別床面積 & 療、学校、集合住宅、戸建住宅の 7 区分の延床面積 \\
グロス容積率 & メッシュデータに含まれる用途別延床面積を合計 \\
& し、メッシュ面積 $\left(250,000 \mathrm{~m}^{2}\right)$ で除して算出した。 \\
& ただし住宅は含まない。 \\
& 平均階数 \\
& 出した別延床面積の合計值を 1 階床面積で除して算 \\
& 出した \\
\hline
\end{tabular}

用途別床面積データを得るため、2001 年に大阪市都市計画調整局 によって行われた建物床面積調査の結果 ${ }^{9)}$ を用いた。本データを 2001 年データとする。2001 年データは、 $500 \mathrm{~m}$ 四方、 $250 \mathrm{~m}$ 四方のメ ッシュ単位、区・町丁目・街区単位、市単位の区分で用途別延床面 積が整備されている。500m 四方のデータは前述の $500 \mathrm{~m} \times 500 \mathrm{~m}$ メッ シュを用いている。2001 年データは建物の用途を「住宅」「商業」「医 療厚生」「工場」「運輸」「供給処理」に区分しており、さらに住宅は 「共同住宅」「長屋住宅」「併用住宅」、商業は「商業（店舗）」「商業 (事務所)」「商業 (遊興娛楽)」「商業（宿泊）」、運輸は「運輸（倉庫）」 とそれぞれ内訳が示されている。なお、「商業（店舗）」「商業（事務 所）」に関しては、さらに「商業（店舗・百貨店）」「商業（事務所・ 銀行)」と内訳が示されている。

2001 年データは固定資産税台帳をもとに作成したものであり、非 課税建築などのデータを含んでいない。そこで、非課税建築につい ては 1985 年の建物床面積調查のデータ ${ }^{10)}$ (以下、1985 年データと 記す）によって非課税建築のストックデータを追加した。1985 年デ ータは非課税建築の情報を収録した最も新しいデータであり、2001 年データと同様にメッシュ単位、区・町丁目・街区単位、市単位で データが整備されている。1985 年データによって追加した非課税建 築データは、「文教」「文教 (学校)」「文教 (寺社)」「医療厚生」「医 療厚生 (病院)」「官公署」用途である。

これらの用途別床面積データを業務部門の事務所、商業、宿泊、 医療、文教、家庭部門の戸建住宅、集合住宅の 2 種類に分類した。 分類の方法を表 3 に示寸。

以上の手順で得られた事務所、商業、宿泊、医療、学校の 5 用途 の延床面積を合計し、メッシュ面積 $\left(250,000 \mathrm{~m}^{2}\right)$ で除し、これを グロス容積率とした。また、5 用途の床面積を各用途の 1 階部分の 面積で除し、平均階数とした。1 階部分の面積は 2001 年データ、1985 年データに集計されているデータを表 3 の用途で分類し、業務部門 の用途で合計したものである。
次に、表 2 に示した各データを入力データとしてクラスター分析を 行い、メッシュデータを類型化した。クラスター分析には階層的手 法を用い、距離は平方ユーグリッド距離、クラスター合併アルゴリ ズムはWard 法を用いた。

表 3 用途の分類

\begin{tabular}{|c|c|}
\hline 用途 & 該当する用途に含まれる 2001 年データ、 1985 年データ \\
\hline 事務所 & 商業（事務所）と官公署の床面積 \\
\hline 商業 & 商業（店舗）と商業（遊興娛楽）の床面積 \\
\hline 泊 & 商業（宿泊）の床面積 \\
\hline 医療 & 以下のデータの合訃 \\
\hline & $\begin{array}{l}-1985 \text { 年データの医療厚生（病院）の床面積 } \\
\text { - } 2001 \text { 年データ医療厚生床面積から } 1985 \text { 年データ应 } \\
\text { 厚生（病院）床面積を引いた面積 }\end{array}$ \\
\hline 学校 & $\begin{array}{l}1985 \text { 年データ文教の床面積から文教 (寺社) の床面積を } \\
\text { 引いた床面積 }\end{array}$ \\
\hline & 共同住宅 $\sigma$ \\
\hline
\end{tabular}

\section{（2）地区類型代表メッシュの決定と代表メッシュの建築ストック 集積状況の調査}

（1）によって得られた地区類型別にグロス容積率、用途別床面積比 率が平均值に最も近いメッシュを代表地区として選択した。次に、 代表地区内に立地するすべての業務建築を対象として表 4 の情報を 収集した。基準階床面積の把握には、大阪市計画調整局の土地利用 現況調査 ${ }^{11)}$ の結果を用いた。本データはGIS データとしてまとめら れており、建物単位の情報が集計されている。延床面積は基準階床 面積と階数の積で推計した。表 4 は調查方法の概要を併せて示寸。

\begin{tabular}{|c|c|c|}
\hline 属性の分類 & 属性 & 調査方法 \\
\hline 立地環境条件 & $\begin{array}{l}\text { 隣接建物の状況 } \\
\text { 隣接棟までの距離と } \\
\text { 粼接棟高さ }\end{array}$ & $\begin{array}{l}\text { 現地調査 } \\
\text { 現地調查 }\end{array}$ \\
\hline 規模 - 形状 & $\begin{array}{l}\text { 建物基準階床面積 } \\
\text { 基隻階アスペクト比 } \\
\text { 階数 } \\
\text { ゾーニング } \\
\text { 方位別空面積比率 } \\
\text { 主用途 } \\
\text { 階層別用途 }\end{array}$ & $\begin{array}{l}\text { 土地利用現況調査 } \\
\text { 土地利用現況調査 } \\
\text { 住宅地図 } \cdot \text { 現地調査 } \\
\text { 現地調查 }^{\text {現地調查 }^{\dagger}} \\
\text { 現地調查 }^{\text {現地調查 }}\end{array}$ \\
\hline
\end{tabular}

†目視でファサード面に対する空面の面積の比率を概算した

\section{（3）地区類型代表メッシュにおける設備ストック集積状況の予測}

ここでは代表地区における空調熱源システムおよび省エネルギー 手法の採用状況を予測する。ここでは著者ら ${ }^{6)}$ による竣工設備デー タベースを用いた。データベースのうち、空調熱源システムについ てのものは図 1 に示した通りである。省エネルギー手法についても 1993 年から 2006 年までに空気調和・衛生工学会に発表された竣工 設備データ7)を用い、空調熱源システムと同様の整理を行っている。 具体的には、省エネルギー手法の採用状況として全熱交換器、外気 冷房、VAV、VWV、大温度差搬送の 5 つの省エネルギー手法の採用状 況を集計しており、これを水準 1 から水準 5 の 5 段階で整理してい る。水準 1 には一つも省エネルギー手法が採用されていなかった建 物の比率、水準 2 から水準 4 は最も採用率が高いものから 1 つ、2 つ、3 つずつ省エネルギー手法、水準 5 は 4 つ以上の手法が採用さ れている建物の比率が整備されている(図 3 )。本研究ではこの結果 


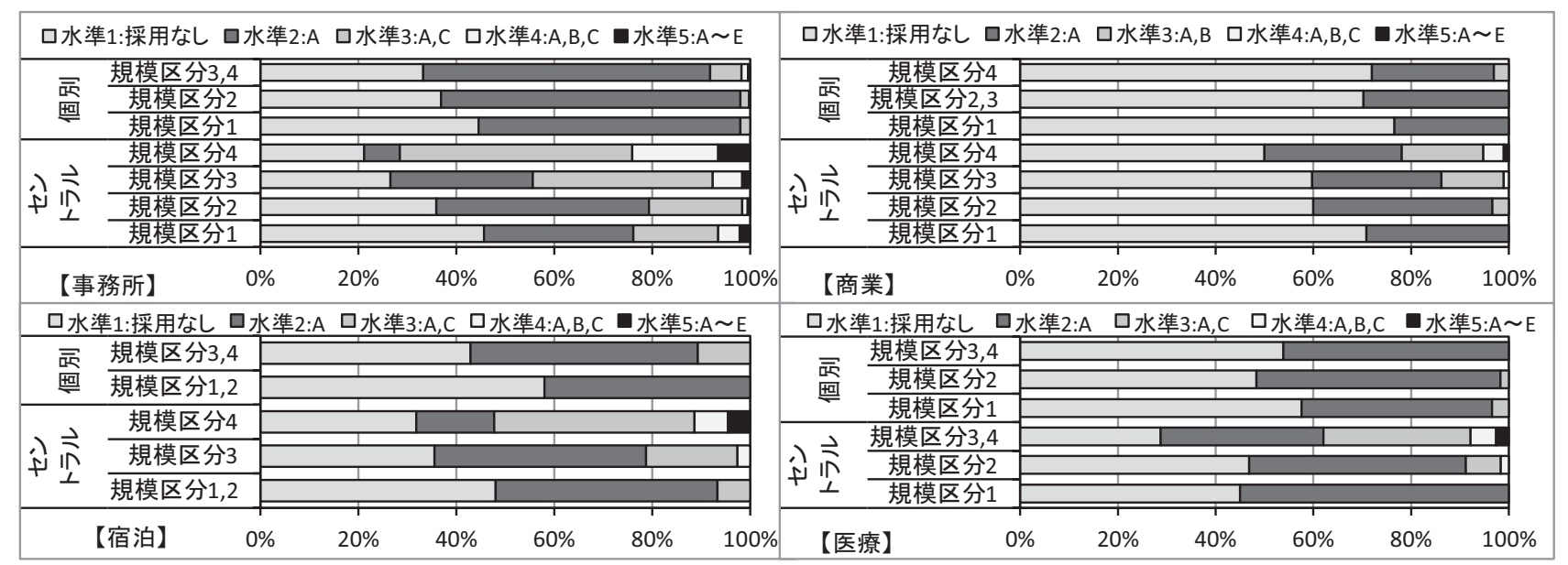

図 3 用途別・規模別省エネルギー手法採用状況（A:全熱交換器， B:外気冷房， C: VAV 搬送， D:VWV 搬送， E: 大温度差搬送）

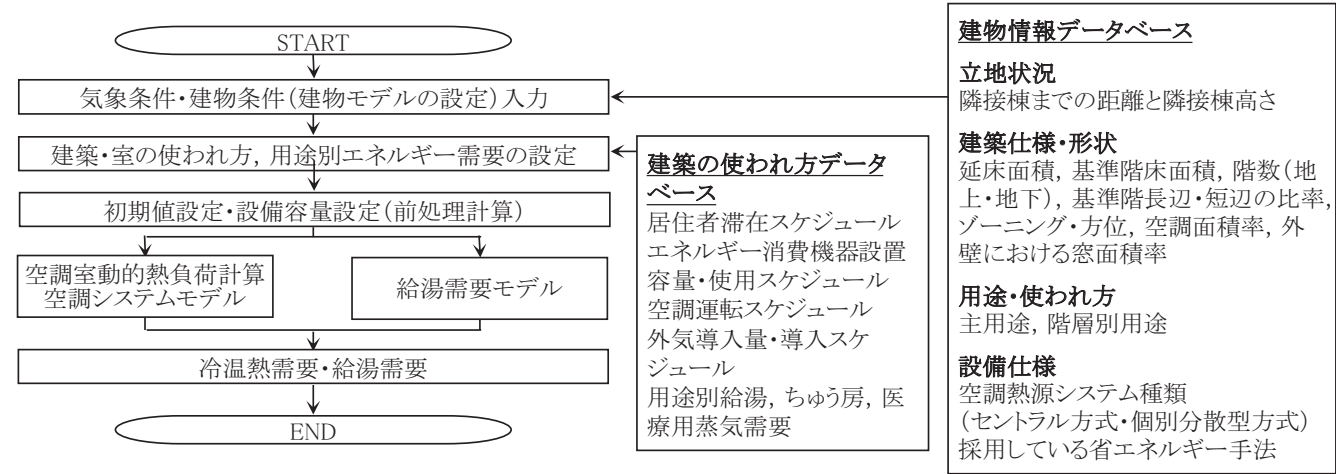

図 4 地域エネルギーシステムモデルの計算フロー

をそのまま用いた。ただし、冷温熱需要を直接増減させる手法は全 熱交換器および外気冷房のみである。そのほかの搬送系統に関する 省エネルギー手法は、各手法の導入によるファンあるいはポンプの 電力消費量の減少によって、間接的に熱需要を増減させる。

以上より得られたセントラル方式と個別分散型空調方式の比率、 省エネルギー手法の採用比率を用いて、地区類型代表メッシュにお けるセントラル方式と個別分散型空調方式の比率、省エネルギー水 準の比率を推計した。

（4）地域エネルギーシステムモデルによる地区類型代表メッシュ の熱需要シミュレーション

ここでは著者らが開発している地域エネルギーシステムモデル 12) 13) 14)を代表地区に適用し、熱需要を推計する注 1)。本モデルでは、 対象地区に立地する建物 1 棟毎に泠温熱需要、給湯需要を推計する。 図 4 に推計手順を示す。

冷温熱需要のシミュレーションでは、すべての建物を対象として 熱源空調システム（セントラル方式、個別分散型空調方式の 2 種） と省エネルギー手法の組み合わせ（水準 1 水準 5 の 5 種）を想定 して冷温熱需要を推計し、（3）で整備した用途別・規模別の空調熱源 システム採用比率、省エネルギー水準の比率によって結果を重み付 け平均して建物の冷暖房需要とする。さらに、得られた需要データ をすべての業務建築について積算し、地区の全業務部門延床面積で 除すことで、地区類型の冷温熱需要原単位とする。この方法によっ て、代表地区に集積する建物の大きさや形状、設備仕様、用途、使 われ方それぞれの影響を含む熱需要原単位を得ることができる。ま た、地区に立地する建物に何らかの傾向があるのであれば、その結
果推計される熱需要原単位は地域の特徴を反映したものになる。給 湯需要についても同様である。

（5）大阪市における熱需要推計結果と地域冷暖房可能性地域評価 メッシュデータとして整備された業務建築延床面積合計值と前節 において定量化した地区類型別の冷暖房需要、給湯需要原単位の積 をとり、各メッシュの熱需要とする。

次に、得られた結果から、地域冷暖房の導入可能性を検討する。 地域冷暖房施設の導入可能地区の抽出条件は、冷温熱需要、給湯需 要の合計值が $1 \mathrm{Tcal} / \mathrm{ha}^{1)}=105 \mathrm{TJ} /$ メッシュ以上となる地区とした。 ここで、すべての建物を考慮して熱需要原単位を推計した場合、セ ントラル方式を採用している建物のみを対象として熱需要原単位を 推計した場合の二つの結果を示す。

\section{3. 大阪市の地区類型化と類型別建築ストック・設備集積状況調査 (1) 大阪市の地区類型化結果}

クラスター分析の結果から大阪市域を 13 類型に分類した。結果を図 5 に示す。各類型の用途別延床面積の平均值（1 メッシュあたり） を図 6 に示す。地区 12 (集積商業地区) については、ストックの集 積状況が大きく異なるメッシュが同じ類型に含まれたことからこれ を二つの類型（CL12-1、CL12-2）に分割することとし、それぞれ代 表地区を決定した。CL12-1、CL12-2 はいずれも商業施設が高密度に 集積しているが、CL12-2 は大阪駅前地区の 1 メッシュで大型の建物 が多く、一方 CL12-1 は大型の建物が立地する地区と中小規模の建物 が多数高密に立地している地区が混在している。CL12-1 の代表地区 は千日前地区である。また、以降の検討では、住宅地であり平均グ 
ロス容積率が 50\%未満である地区類型 4 から 9 までに含まれる地区 を、地域冷暖房施設導入の可能性は小さいと考えて検討の対象外と した。

（2）地区類型代表メッシュの決定と代表メッシュの建築ストック集 積状況の調査

各地区類型の代表メッシュと代表地区の調查によって得られた地 区類型の特徴を表 5 に示す。また、代表地区における業務建築の規 模の分布を図 7 に示す。
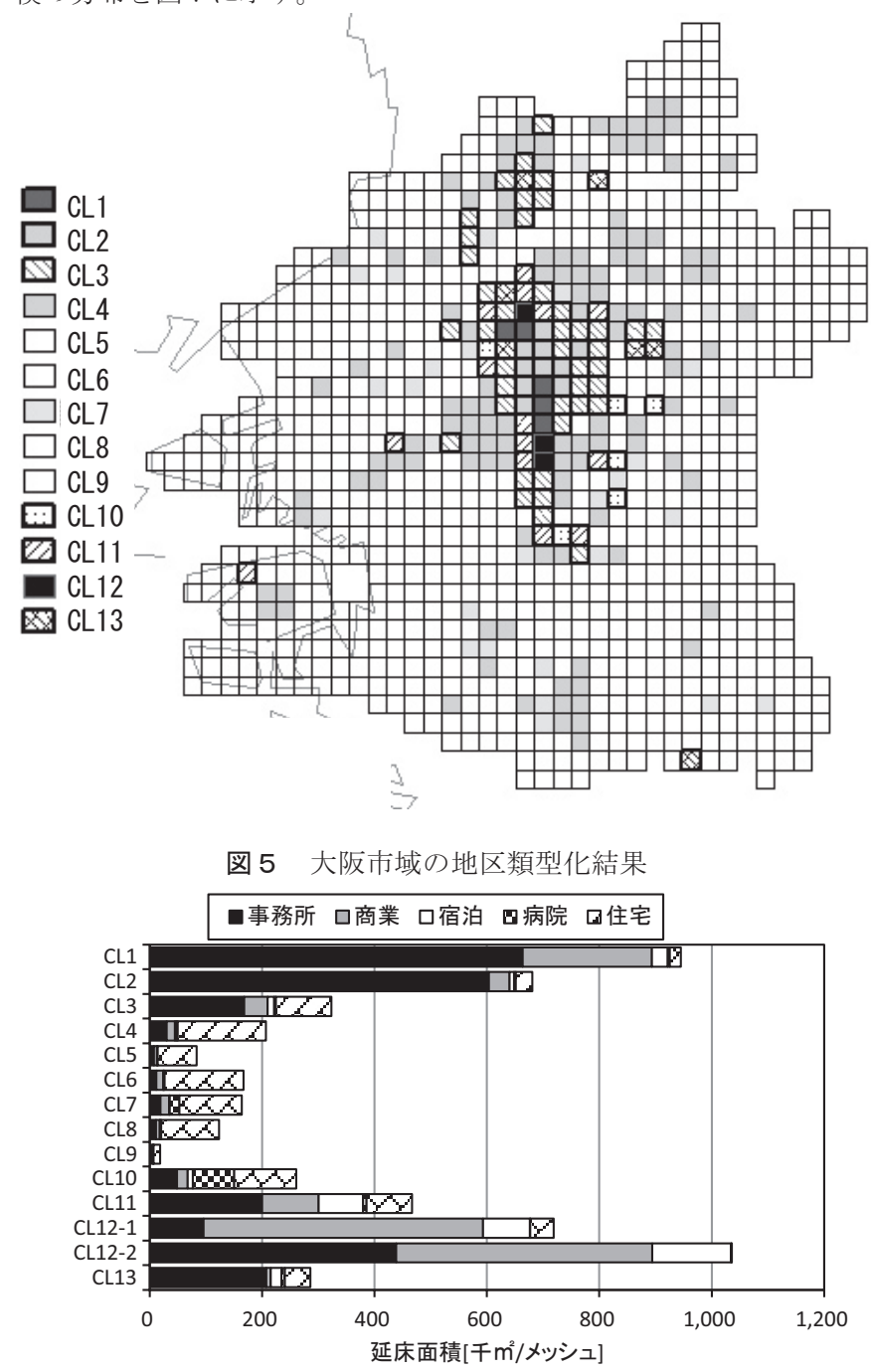

図 6 地区別用途別平均延床面積

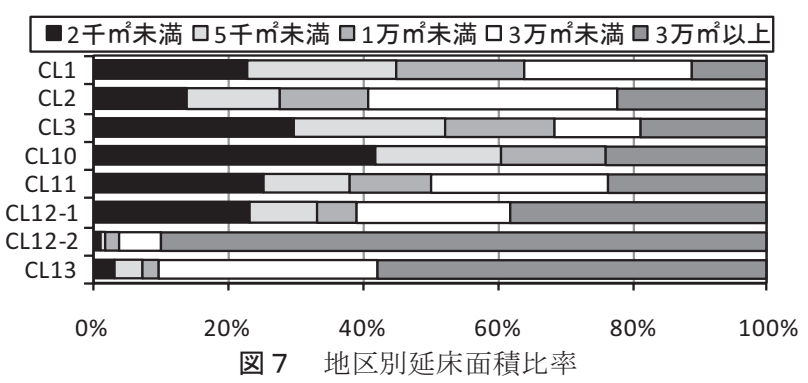

（3）地区類型代表地区における設備ストック集積状況の予測

各代表地区の空調熱源システムの比率、省エネルギー水準の比率 の推計結果を図 8 に示す。

図からわかるように、密度の高い地区では多くの省エネルギー手 法が使用されており、セントラル方式が多く用いられている。一方、 密度が低い地区では個別分散型空調方式の比率が高い。この結果は、 建築ストックの集積形態によって設備仕様の設置状況に差異が生じ ていることを意味する。



図 8 地区別空調熱源システム比率（上） と省エネルギー水準比率（下）

\section{4. 地区類型代表地区の熱需要推計}

代表地区について冷暖房需要、給湯需要を推計した結果を図 9 、 図 10 に示寸。図 9 は (1) (4) の図より構成されるが、左から二つの 図（(1) と (2)）は地区類型別の熱需要原単位を示す。図 9 右二つの 図（(3)と（4)）は熱需要の積算值を示す。図 10 は熱需要原単位を月 別に表示したものである。

表 5 代表メッシュの建築ストック集積状況の特徴

\begin{tabular}{|c|c|c|c|c|c|c|}
\hline 記号 & 地区類型名称 & $\begin{array}{l}\text { メッシ } \\
\text { ユ数 }\end{array}$ & 代表地区 & $\begin{array}{l}\text { 業務建築の } \\
\text { グロス容積率 }\end{array}$ & 用途構成 & 代表地区における建物立地状況の特徵 \\
\hline CL1 & 集積業務 & 5 & $\begin{array}{l}\text { 中央区 } \\
\text { 久太郎町 }\end{array}$ & $300 \sim 400 \%$ & 床面積の $70 \%$ は事務所用途。 & $\begin{array}{l}\text { 中小規模の商業施設、事務所ビルから } 10,000 \mathrm{~m}^{2} \text { 以上の事 } \\
\text { 務所建築まで混在している。 }\end{array}$ \\
\hline CL2 & 集積事務所 & 9 & 中央区本町 & $200 \sim 300 \%$ & 床面積の $85 \%$ は事務所用途。 & 大規模な事務所が集積している。 \\
\hline CL3 & $\begin{array}{l}\text { 中密度住宅業 } \\
\text { 務混在 }\end{array}$ & 41 & $\begin{array}{l}\text { 北区 } \\
\text { 中崎町 }\end{array}$ & $200 \%$ 未満 & $\begin{array}{l}\text { 床面積の } 50 \% \text { は事務所用途、 } \\
30 \% \text { は住宅。 }\end{array}$ & 中小規模の建物が集積しており、集合住宅が多い。 \\
\hline CL10 & 医療厚生 & 6 & $\begin{array}{l}\text { 天王寺区 } \\
\text { 松ヶ鼻町 }\end{array}$ & $80 \%$ 未満 & $\begin{array}{l}7 \text { 万 } \mathrm{m}^{2} \sim 10 \text { 万 } \mathrm{m}^{2} \text { の医療施設が存在。 } \\
\text { 他の用途では床面積は小さい。 }\end{array}$ & 医療施設以外は小規模建築によって構成されている。 \\
\hline CL11 & 中規模商業 & 14 & $\begin{array}{l}\text { 浪速区 } \\
\text { 湊町 }\end{array}$ & $300 \%$ 未満 & $\begin{array}{l}\text { 床面積の } 20 \% \text { は商業用途。集合住宅 } \\
\text { は他の住宅地区と同程度存在する。 }\end{array}$ & $\begin{array}{l}\text { 中小規模建築が密集しているが、10,000 m²以上の建築も } \\
\text { 立地している。 }\end{array}$ \\
\hline CL12-1 & 集積商業 & 2 & $\begin{array}{l}\text { 中央区 } \\
\text { 千日前 }\end{array}$ & $250 \sim 400 \%$ & 床面積の 60\%は商業用途。 & $\begin{array}{l}\text { 大規模建築が立地する地区と中小規模建築の密集する地 } \\
\text { 区が混在している。 }\end{array}$ \\
\hline CL12-2 & 集積商業 & 1 & $\begin{array}{l}\text { 北区梅田 } \\
\text { (大阪駅周辺) }\end{array}$ & $600 \%$ & $\begin{array}{l}\text { 約 } 60 \% \text { は事務所、そのほかは商業、 } \\
\text { 宿泊に使用されている。 }\end{array}$ & 超高層ビル、大規模ビルが集積している。 \\
\hline CL13 & $\begin{array}{l}\text { 集積住宅事務 } \\
\text { 所混在 }\end{array}$ & 7 & $\begin{array}{l}\text { 北区 } \\
\text { 中之島 }\end{array}$ & $100 \sim 200 \%$ & $\begin{array}{l}\text { 床面積の } 70 \% \text { は事務所用途。 } \\
\text { 集合住宅も } 10 \% \text { 存在する。 }\end{array}$ & $\begin{array}{l}\text { 大規模事務所や高層集合住宅が比較的まばらに立地され } \\
\text { ている。 }\end{array}$ \\
\hline
\end{tabular}


図 9 (1)を見ると、地区類型別の熱需要原単位は最少 $500 \mathrm{MJ} / \mathrm{m}^{2} \cdot$ 年 $900 \mathrm{NJ} / \mathrm{m}^{2}$ ・年と大きくばらついている。この数值は代表メッシ ユに集積する建物の規模、使われ方、それに付随する省エネルギー 手法の採用状況を内包するものである。比較的事務所の比率が高い CL1、CL2、CL13 を比較すると、建物規模が大きい CL13 においても っとも原単位が小さい。また、事務所の比率が高い類型よりも、商 業施設の比率が高い CL10〜CL12 の類型において熱需要原単位が大 きい。

図 9 (2)にセントラル方式を採用している建物の熱需要と全建物 の熱需要の比率を示す。図からわかるように、商業施設の比率が高 いCL12-1、大規模な建物が延床面積の大部分を占める CL12-2（大阪 駅前地区)、CL13（大阪市中之島）は熱需要全体に占めるセントラル 方式の建物の熱需要の比率が高い。図 9 (1)、（2）を比較すると、上 記の比率が低い地域は熱需要合計值が大幅に減少していることがわ かる。この結果、事務所の比率が高い CL1、CL2、CL13 を比較すると、 CL1 が最少となり、CL2 と CL13 は同等となった。これは建物規模の 影響でCL1、CL2、CL13 の昇順でセントラル方式を採用している建物 の比率が大きいためである (図 8 )。このように、大型の建物で構成
される地区では全建物の熱需要に基づいて地域冷暖房導入可能性評 価を行っても両者の差異は小さいが、密度が高く中小規模の建物が 多く立地する地区においては、図中 (1) (2)の数值が大きく異なる。

図 9 (3) (4) は熱需要合計值を示すが、(3) 全建物の熱需要合計值で はすべての類型において熱負荷密度が $1 \mathrm{Tcal} /$ 年・ha（105TJ/年・メ ッシュ）を超える。一方、（4）セントラル方式を採用している建物の 熱需要の夕に限定すると、CL3、CL10 は熱負荷密度 $1 \mathrm{~T}$ cal/年・ha を 下回る。図 10 に示した月別の熱需要を見ると、全建物の熱需要 (左) はすべての地区類型において熱需要が $20 \mathrm{MJ} / \mathrm{m}^{2}$ ・月を超えているが、 セントラル方式を採用している建物に限定寸ると、CL12-1、CL12-2 を除き、 4 月、 11 月における熱需要が $20 \mathrm{MJ} / \mathrm{m}^{2}$ ・年を下回っている。

5. 大阪市における熱需要推計結果と地域冷暖房可能性地域の評価 大阪市域の全メッシュを対象として熱需要の推計を行った結果を 図 11、図 12 に示す。図 11 はすべての建物の熱需要、図 12 はセン トラル方式を採用している建物の熱需要を推計したものである。図 11 を熱需要の上限值、図 12 を下限值と考えることができる。

図 11 において、熱負荷密度が $1 \mathrm{Tcal} /$ 年・ha（105TJ/年・メッシ
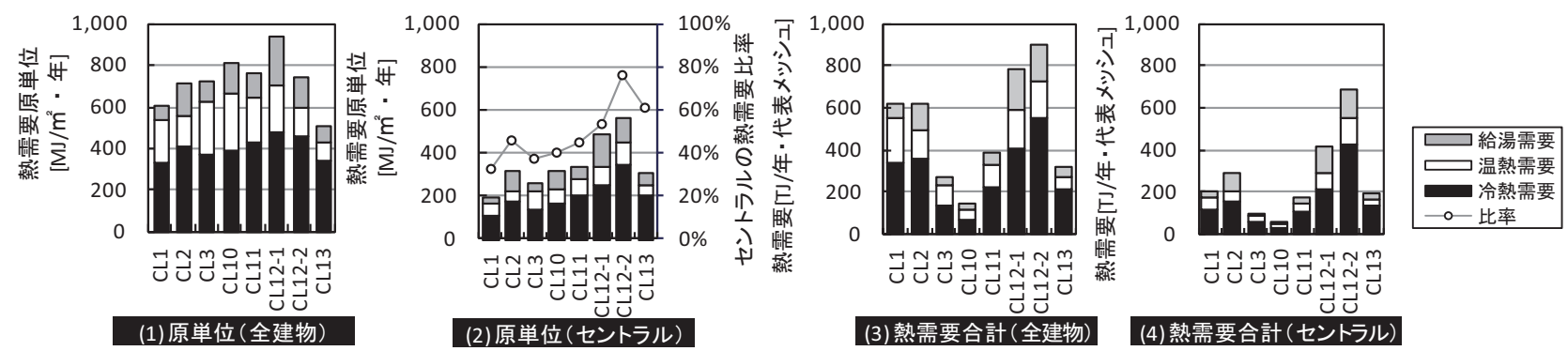

図 9 地区類型別の熱需要推計值およびセントラル方式を採用している建物の熱需要の比率 $(2)$
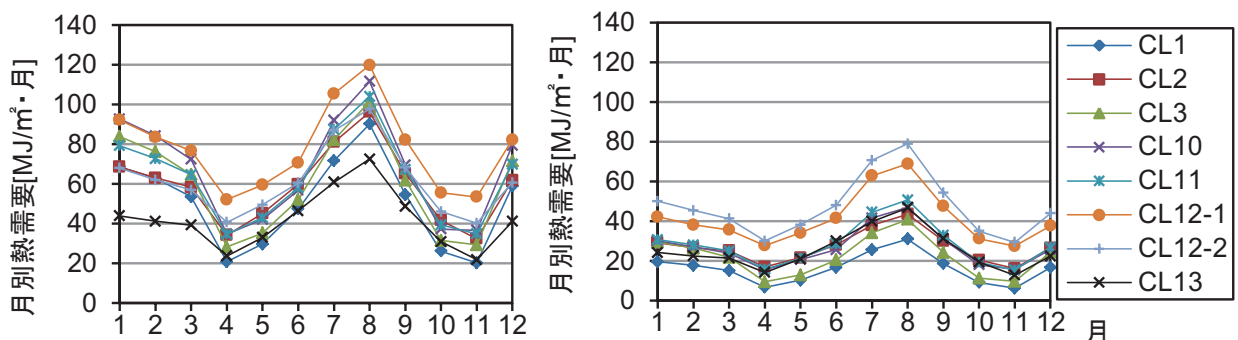

図 10 地区類型別の月別冷熱、温熱、給湯需要原単位（左は全建物の熱需要、右はセントラル方式を採用している建物の熱需要）

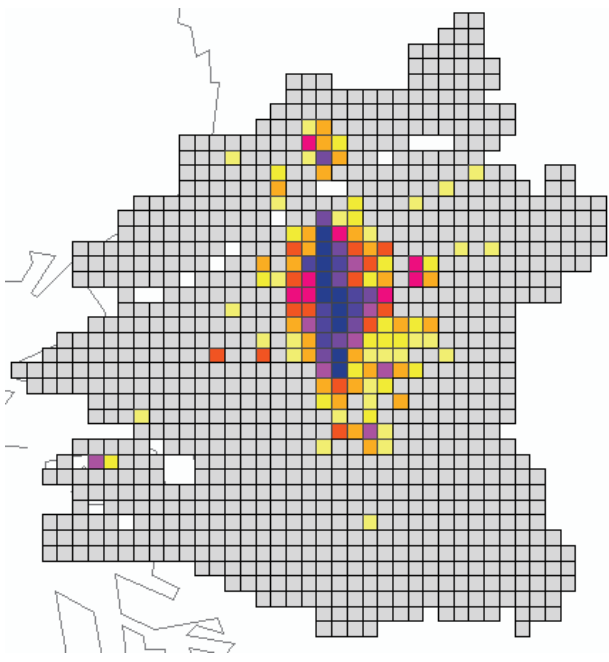

図 11 全建物の熱需要の分布

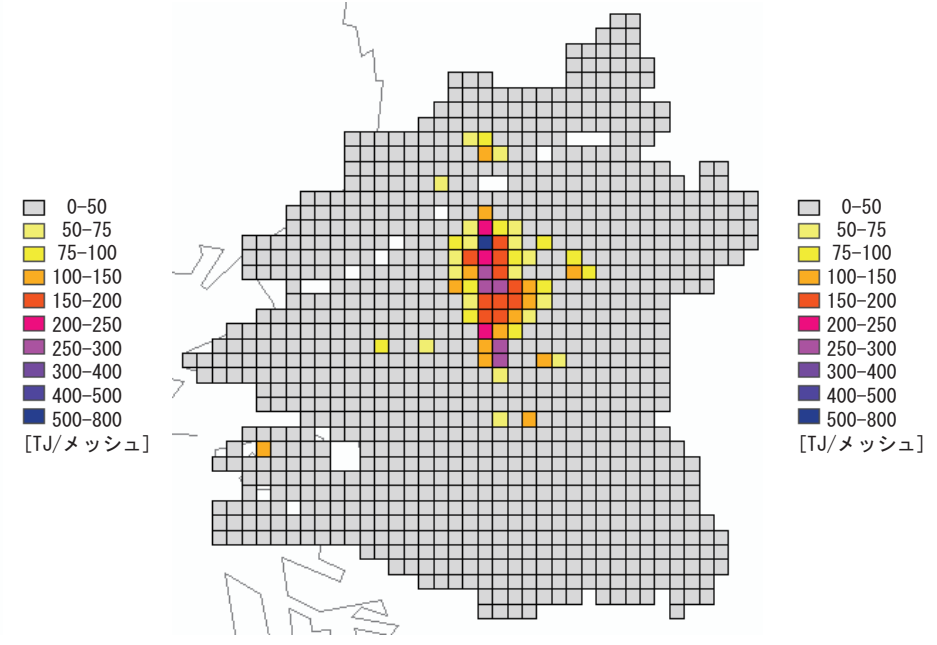

図 12 セントラル方式を採用している建物の熱需要の分布 
ユ）を超えるメッシュは 78 メッシュとなり、合計 $21 \mathrm{PJ} /$ 年の熱需要 が存在する結果となった。ただし、セントラル方式を採用している 建物のみが地域冷暖房施設に接続することができるとすると、図 12 のように 33 メッシュが抽出条件を満たし、抽出されたメッシュの熱 需要合計值は $6 \mathrm{PJ} /$ 年、全建物の熱需要の $29 \%$ まで減少した。

\section{6. 結論}

本論文は地域冷暖房施設の導入可能性評価に用いる熱負荷密度の 推計において、地区に立地するすべての建物を対象として推計され る熱負荷密度と、個別分散型空調システムを採用している建物を除 いて推計される熱負荷密度を推計し、両者の差異を明らかにするこ とを目的とした。得られた主な結果を以下にまとめる。

・ 上記目的のため、地区内に集積する業務建築 1 件ごとの熱需要 をシミュレーションにより推計し、地区の熱需要をその合計值 により推計した。このような手法により、建築の熱需要を決定 する要因である建築仕様、設備仕様、建築の使われ方の影響を 考慮することができる。また、今回の論文の範囲ではないが、 照明技術の高効率化など、将来の状況を想定した検討も可能で ある。

・ 大阪市を対象としたケーススタディでは、熱負荷密度が 1Tcal/ 年・ha を超える 500 メートルメッシュは、78メッシュ存在し、 その熱需要合計值は $21 \mathrm{PJ} /$ 年となるものの、地域冷暖房施設には セントラル方式を採用している建物のみが接続することができ るとすると 33 メッシュであり、熱需要合計值は $6 \mathrm{PJ} /$ 年まで減少 した。

- 既成市街地を対象として地域冷暖房施設の導入可能性評価を行 う場合、業務部門の部門別熱需要原単位を用いて評価を行うこ とで、判定結果は過大評価となる可能性がある。その程度は地 区の特徵によって異なり、たとえば、熱需要密度が高い建物で あっても、比較的規模の小さい建物が高密に集積している地区 であれば大きくなる。

以上より本論文は熱需要の推計において空調熱源システムの採用 状況を考慮することによって熱負荷密度の推計結果が大きく異なる ことを明らかにすることができたと考えられる。しかし、以下の点 について十分ではないと考えられることから、この点を今後の課題 とする。

・ 本論文では既報 ${ }^{8)}$ で発表したモデルを利用したことから、モデ ルで使用している 500 メートルメッシュデータを用いた。一方、 地域冷暖房施設の導入は街区やもう少し小さい空間を単位とし て計画がなされると考えられ、より小さいメッシュデータを利 用した推計が必要であると考えられる。この場合、局地的に熱 負荷密度が高い街区が地域冷暖施設導入可能地区として選択さ れると考えられ、地域冷暖房施設導入可能条件を満たす地区は 今回の結果よりも多くなると考えられる。

・また、地区類型に用いたデータも 2001 年、1985 年の固定資産 税台帳に基づくものであり、最新のものではない。また、代表 メッシュにおける熱負荷密度の推計においても、将来の計画に 用いる分析であれば、照明技術の高効率化など、将来の状況を 想定することも必要であると考えられる。大阪市における地 域冷暖房施設の導入可能性評価を行うためには、分析に用い
るデータベースの更新が必要であると考えられる。

\section{謝辞}

本研究は社団法人都市環境エネルギー協会「大都市圏における高 温系未利用エネルギー活用可能性検討」研究（委員長 : 尾島俊雄早 稲田大学名誉教授）の一環として行われたものである。助言、支援 をいただいた関係各位に謝意を表する。

注

注 1）モデルの冷温熱需要推計モデルは、HASP/ACLD851 における熱負荷モデ ルを改良し、コイル、エアハンドリングユニット、ファンコイルユニット、 個別分散型空調システム室内機等の空調機システムのモデルを追加したも のである。詳細は文献 12) に詳しい。文献 12)ではファンコイルユニット、 エアハンドリングユニットにおける冷水熱消費量を行っている事務所 1 フ ロア（約 100 名が在籍）に対してモデルを適用し、実測結果との比較によ り精度を確認している。文献 14)では 31 棟の事務所ビルについて年間・月 別の電力消費量、都市ガス消費量と推計結果の比較を行った。推計では本 論文と同様表 4 の情報を入力情報として収集した。この結果、個々の建物 の消費量については、少数の建物について実測結果と推計值が大きくかい 離するものがあるものの、年間值では電力は $3 \%$ 、都市ガスでは $9 \%$ の誤差 となるなど、多数の建物の合計值では、推計值と実績值がよく一致してい ることを確認した。

\section{参考文献}

1）佐土原聡，長野克則，三浦昌生，村上公哉，森山正和，下田吉之，片山 忠久，依田浩敏，北山広樹：日本全国の地域冷暖房導入可能性と地球環 境保全効果に関する調査研究, 日本建築学会計画系論文集, No. 510, pp. $61-67,1998.8$

2）河原透, 佐土原聡, 尾島俊雄 : 低温熱媒地域冷暖房導入に伴う東京の地 区分類に関する研究, 日本建築学会計画系論文報告集, No. 448, pp. 29-38, 1993. 6

3）三浦昌生：埼玉県下の主要商業地域における用途別延床面積と地域冷暖 房導入可能エリア：現状の熱需要からみた検討, 日本建築学会計画系論 文集，No. 484，pp. 63-71，1996.6

4）依田浩敏，北山広樹，片山忠久，西田勝：九州地域における未利用エネ ルギー活用に関する研究，日本建築学会計画系論文集，No. 517，pp. 99-105, 1999. 3

5）下田吉之，水野稳，亀谷茂樹，百瀬敏成，金地孝行 : 都市未利用エネル ギーの活用可能性評価手法に関する研究 第 1 報一大阪市における各熱 源の利用可能量と熱需要に関寸る調査と分析，空気調和・衛生工学会論 文集，No. 61，pp. 67-77，1996.4

6）山口容平, 下田吉之, 水野稔：建築・設備ストックの集積状況を考慮した 大阪市の民生業務部門エネルギー需要モデルの開発と温暖化対策の評価, 日本建築学会環境系論文集，No. 641，pp. 853-862，2009.7

7）（社）空気調和・衛生工学会：竣工設備調査用紙一覧 1984 2006

8) Yamaguchi, Y., Shimoda, Y., Mizuno, M. : Proposal of a modeling approach considering urban form for evaluation of city level energy management, Energy and Buildings, Vol. 39, pp. 580-592, 2007.5

9）大阪市都市計画調整局：建物床面積調査，2001

10）大阪市都市計画調整局：建物床面積調査，1985

11）大阪市都市計画調整局：平成 12 年度大阪市土地利用現況調査， 2000

12）山口容平,下田吉之, 水野稔：居住者の行動を基準としたオフィスビルの 熱・電力需要シミュレーションモデルの開発, 空気調和・衛生工学会論 文集，No. 93，pp. 37-47，2004.4

13) Yamaguchi, Y., Shimoda, Y., Mizuno, M: Transition to a sustainable urban energy system from a long-term perspective: Case study in a Japanese business district, Energy and Buildings, Vol. 39, pp. 1-12, 2007. 1

14) Yamaguchi, Y., Shimoda, Y.: District-scale Simulation for Multi-purpose Evaluation of Urban Energy System”, Journal of Building Performance Simulation, Accepted, 2010

（2010年 7 月 9 日原稿受理，2011年 1 月 20日採用決定） 